(E-ISSN : 2615-4978, P-ISSN : 2086-4620)

Vol XI No 3, Nopember 2020

\title{
Analisis Arus Kas (Studi Empiris Pada PT. Indosat Tbk)
}

\author{
Risa Ratna Gumilang \\ STIE Sebelas April Sumedang \\ risa.rgumilang@gmail.com
}

\begin{abstract}
ABSTRAK
Laporan arus kas merupakan laporan yang menunjukan aliran kas atau dana tunai yang ada pada perusahaan. Laporan kas terdiri dari arus kas masuk seperti hasil penerimaan atau penjualan dan arus kas keluar yang terdiri dari pengeluaran seperti pembayaran beban dan biaya. Tujuan penelitian ini adalah untuk mengetahui kemampuan PT. Indosat Tbk. dalam mengelola arus kas terutama dalam menentukan proyeksi investasi yang di lakukan, berdasarkan kondisi arus kas PT. Indosat Tbk pada periode 20162018. Hasil penelitian ini menunjukan bahwa analisis perbandingan laporan arus kas pada total kas dan setara kas, arus kas diakhir periode selama periode 2016-2018 menunjukan persentase -48.93\%, 4.10\%, 45.75\%, selama tiga tahun berturut turut, dan pada analisis Trend yang ada pada PT. Indosat Tbk. menunjukan angka persentase $51,07 \%, 104,10 \%, 54,25 \%$ selama tiga tahun berturut turut pada periode 2016-2018. Analisa perkomponen menunjukan bahwa arus kas masuk dan kas keluar di dominasi oleh arus kas dari aktivitas operasi dengan kecenderungan bahwa arus kas masuk mengalami penurunan sedangkan arus kas keluar mengalami kenaikan. Pada analisis rasio arus kas khusus menunjukan bahwa rasio kecukupan arus kas PT. Indosat Tbk, menunjukan angka sebesar 1,57 dan rasio reinvestasi yang menunjukan rasio sebesar $25,65 \%$ yang berarti bahwa PT. Indosat Tbk cukup baik dalam mencukupi keperluan dana tunai perusahaan.
\end{abstract}

Kata Kunci : laporan arus kas, proyeksi arus kas

\begin{abstract}
The cash flow statement is a report that shows the flow of cash or cash that is in the company. The cash statement consists of cash inflows such as proceeds from receipts or sales and cash outflows which consist of expenses such as payment of expenses and expenses. The purpose of this study was to determine the ability of PT. Indosat Tbk. in managing cash flow, especially in determining the projected investment made, based on the cash flow conditions of PT. Indosat Tbk in the period 2016-2018. The results of this study indicate that the comparative analysis of cash flow statements on total cash and cash equivalents, cash flow at the end of the period during the 2016-2018 period shows a percentage of $48.93 \%, 4.10 \%,-45.75 \%$, for three consecutive years, and on Trend analysis is at PT. Indosat Tbk. shows the percentage figures of 51.07\%, 104.10\%, 54.25\% for three consecutive years in the 2016-2018 period. Per component analysis shows that cash inflows and outflows are dominated by cash flows from operating activities with a tendency that cash inflows decrease while cash outflows increase. In a special cash flow ratio analysis shows that the cash flow adequacy ratio of PT. Indosat Tbk, shows a figure of 1.57 and a reinvestment ratio which shows a ratio of $25.65 \%$ which means that PT. Indosat Tbk is quite good at meeting the company's cash needs.
\end{abstract}

Keywords : statement of cash flow, cash flow projection

\section{PENDAHULUAN}

Indonesia kini memasuki era Industri 4.0 atau yang dikenal dengan era digital yang mana, di era ini hampir semua kegiatan sehari-hari terintegrasi dengan internet. Dengan begitu di era ini kebutuhan akan akses internet menjadi hal yang penting, dan tidak dapat dihindarkan. Untuk dapat terhubung dengan internet tentunya diperlukan jaringan yang dapat menghubungkan perangkat ke internet, salah satunya kita mengenal jaringan seluler. Begitu banyak penyedia jaringan seluler di indonesia salah satunya adalah PT. Indosat Tbk. yang telah terdaftar di Bursa Efek Indonesia (BEI).

PT. Indosat Tbk. sebagai salah satu perusahaan provider jaringan seluler terkemuka di Indonesia, dituntut untuk selalu dapat meningkatkan kualitasnya. Tentunya dalam pengembangan perusahaan yang dilakukan PT. Indosat Tbk. melakukan penilaian terhadap laporan keuangan yang ada sebelumnya. Karena dengan mengambil 
keputusan berdasarkan data yang telah ada akan meminimalisir kerugian yang akan dialami perusahaan.

Salah satu jenis laporan keuangan yang dapat dijadikan acuan sebagai pengambilan keputusan yaitu laporan arus kas. Dalam laporan arus kas menunjukan semua aspek yang berkaitan dengan kegiatan perusahaan baik itu yang berpengaruh langsung atau tidak langsung yang terhadap kas. Laporan arus kas terdiri dari laporan arus kas masuk (cash inflow) dan arus kas keluar merupakan (cash outflow). Dengan Analisis arus kas perusahaan, kita dapat menilai ke efisienan perusahaan dalam mengelola kas yang ada untuk kegiatan operasional perusahaan sehari-hari demi mencapai tujuan perusahaan. Sebagai bahan acuan berikut penulis sajikan data laporan keuangan dari PT. Indosat Tbk.

Tabel 1. Laporan Arus Kas PT. Indosat Tbk. Periode 2015-2018

(dinyatakan dalam jutaan rupiah)

\begin{tabular}{lcccc}
\hline Keterangan & $\mathbf{2 0 1 5}$ & $\mathbf{2 0 1 6}$ & $\mathbf{2 0 1 7}$ & $\mathbf{2 0 1 8}$ \\
\hline $\begin{array}{l}\text { Total arus kas } \\
\text { dari aktivitas } \\
\text { operasional }\end{array}$ & 8.706 .671 & 9.751 .515 & 8.960 .936 & 4.161 .943 \\
\hline $\begin{array}{l}\text { Total arus kas } \\
\text { dari aktivitas } \\
\text { investasi }\end{array}$ & $(7,145,364)$ & $(7.291 .386)$ & $(6,772,642)$ & $(5,451,915)$ \\
\hline $\begin{array}{l}\text { Total arus kas } \\
\text { dari aktivitas } \\
\text { pendanaan }\end{array}$ & $(1,527,076)$ & $(4,251,347)$ & $(2,115,406)$ & 624,810 \\
\hline $\begin{array}{l}\text { Jumlah kenaikan } \\
\text { (penurunan) } \\
\text { bersih kas dan } \\
\text { setara kas }\end{array}$ & 34,231 & $(1,791,218)$ & 72,888 & 665,162 \\
\hline $\begin{array}{l}\text { Kas dan setara } \\
\text { kas arus kas, } \\
\text { awal periode }\end{array}$ & $3,480,011$ & $3,623,346$ & $1,850,425$ & $1,674,745$ \\
\hline $\begin{array}{l}\text { Efek perubahan } \\
\text { nilai kurs pada } \\
\text { kas dan setara } \\
\text { kas }\end{array}$ & 109,104 & 18,297 & 3,003 & 35,458 \\
\hline $\begin{array}{l}\text { Kenaikan } \\
\text { (penurunan) kas } \\
\text { dan setara kas } \\
\text { lainnya }\end{array}$ & 0 & $1,850,425$ & $1,926,316$ & $1,045,041$ \\
\hline $\begin{array}{l}\text { Kas dan setara } \\
\text { kas arus kas, } \\
\text { akhir periode }\end{array}$ & $3,623,346$ & & & \\
\hline
\end{tabular}

Sumber : https://www.idx.co.id/,2019.

Pada tabel 1.1 menunjukan laporan arus kas PT. Indosat Tbk diamana arus kasnya tidak selalu mengalami kenaikan namun terhadap beberapa bagian arus kas mengalami penurunan yang cukup signifikan, seperti yang di tunjukan pada tabel selanjutnya :
Tabel 2. Persentase Kenaikan (Penurunan) Arus Kas PT. Indosat Tbk. Periode 2016-2018

(dinyatakan dalam jutaan rupiah)

\begin{tabular}{ccccc}
\hline Tahun & $\begin{array}{c}\text { Persentas } \\
\text { e dan Rp }\end{array}$ & $\begin{array}{c}\text { Arus kas } \\
\text { pada } \\
\text { aktivitas } \\
\text { operasi }\end{array}$ & $\begin{array}{c}\text { Arus kas } \\
\text { pada } \\
\text { aktivitas } \\
\text { investasi }\end{array}$ & $\begin{array}{c}\text { Arus kas } \\
\text { pada } \\
\text { aktivitas } \\
\text { pendanaan }\end{array}$ \\
\hline \multirow{2}{*}{2015} & $\%$ & - & - & - \\
& Rp & - & - & - \\
2016 & $\%$ & $12 \%$ & $2 \%$ & $178,39 \%$ \\
& $\mathrm{Rp}$ & 1.044 .800 & 145.827 & $(2.725 .528)$ \\
2017 & $\%$ & $(8,11 \%)$ & $(7,11 \%)$ & $(50,24 \%)$ \\
& $\mathrm{Rp}$ & $(790.848)$ & 518.417 & 2.135 .876 \\
& $\%$ & $(53,55 \%)$ & $(19,5 \%)$ & $(129,5 \%)$ \\
& $\mathrm{Rp}$ & $(4.798 .581)$ & 1.320 .665 & 2.739 .450 \\
\hline
\end{tabular}

sumber : data yang diolah penulis, 2020.

Berdasarkan tabel 1.2 dapat dilihat bahwa arus kas pada aktivitas operasi mengalami penurunan pada tahun 2017 dan 2018 sebesar 8,11\%, sedangkan pada aktivitas investasi terjadi penurunan pembayaran pada 2017 dan 2018 sebesar $7.11 \%$ dan $19.5 \%$, begitu pun terhadap aktivitas pendaan PT. Indosat Tbk. menurun secara signifikan sebesar $50.24 \%$ dan $129,5 \%$. Hal ini terjadi karena adanya penurunan penerimaan kas dari pelanggan pada tahun 2017 dan penurunan yang signifikan pada tahun 2018, hal ini diduga terjadi karena adanya kenaikan dalam piutang usaha, persediaan, dan beban yang rata rata mengalami kenaikan walaupun kecil (perhitungan terlampir). Walaupun dalam arus kas aktivitas investasi dan pendanaan sendiri di tahun 2017 dan 2018 cenderung mengalami penurunan arus kas keluar.

\section{Rumusan Masalah}

Berdasarkan uraian latar belakang diatas rumusan masalah dalam penelitian ini adalah sebagai berikut :

1. Bagaimana arus kas PT.Indosat Tbk.

2. Bagaimana proyeksi arus kas dalam menilai investasi pada PT. Indosat Tbk.

\section{TINJAUAN PUSTAKA}

\section{A. Laporan Arus Kas}

Laporan arus kas merupakan laporan yang menunjukan semua aspek yang berkaitan dengan kegiatan perusahaan, baik yang berpengaruh langsung atau tidak langsung terhadap kas, laporan arus kas harus disusun berdasarkan konsep kas selama periode laporan. Laporan arus kas terdiri dari arus kas masuk (cash in) dan arus kas keluar (cash out) selama periode tertentu. Laporan Arus kas terdiri kedalam tiga kategori yaitu, aktivitas 
operasi meliputi transaksi-transaksi yang tergolong sebagai penentu besar ruginya laba bersih, aktivitas investasi terdiri dari membeli atau menjual tanah, bangunan, dan peralatan, aktivitas pembiayaan (pendanaan) meliputi transaksi-transaksi yang berkaitan dengan utang jangka panjang maupun ekuitas modal.

\section{B. Analisis Arus Kas}

Dalam menganalisis arus kas PT. Indosat Tbk. penulis menggunakan teknik analisis laporan keuangan berupa:

1) Analisis perbandingan laporan keuangan merupakan analisis ini dilakukan dengan membandingkan laporan keuangan lebih dari satu periode.

$\frac{\text { jumlah tahun ini-jumlahtahun dasar }}{\text { jumlah tahun dasar }} \times 100 \%$

2) Analisis Trend atau tendensi merupakan analisis leporan keuangan yang dinyatakan dalam persentase tertentu.

$\frac{\text { jumlah tahun pembanding }}{\text { jumlah tahun dasar }} \times 100 \%$

3) Analisis persentase perkomponen (common size) merupakan teknik analisis yang dilakukan untuk membandingkan antara komponen yang ada dalam suatu laporan keuangan.

$$
\begin{aligned}
& \frac{\text { total arus kas masuk }}{\text { arus kas masuk tiap aktivitas }} \times 100 \% \\
& \frac{\text { total arus kas keluar }}{\text { arus kas keluar tiap aktivitas }} \times 100 \%
\end{aligned}
$$

Dan dua analisis rasio arus kas khusus yaitu :

1) Rasio Kecukupan Arus Kas adalah ukuran kemampuan perusahaan untuk menghasilkan kas operasi yang cukup untuk menutupi pengeuaran modal, investasi pada persediaan, dan deviden tunai.

$\frac{\text { jumlah kas dari aktivitas operasi }}{\text { jumlah pengeluaran modal+ }}$

penambahan persediaan+deviden tuna

2) Rasio reinvestasi kas oleh Subramanya (2017:22) diartikan sebagai ukuran atas persentase investasi dalam aset yang mencerminkan kas operasi yang ditahan dan diinvestasikan kembali oleh ke perusahaan untuk mengganti aset pertumbuhan operasi.

\footnotetext{
$\frac{\text { kas operasi-deviden }}{\text { aset tetap bruto+investasi+aset lain-lain }+} \rightarrow$ modal kerja
}

\section{METODE PENELITIAN}

Penelitian ini menggunakan metode pendekatan deskriptif kualitatif karena hal ini sesuai dengan tujuan untuk memperoleh gambaran yang nyata mengenai analisis arus kas pada PT. Indosat Tbk. tanpa menggeneralisasi objek dan lebih memperdalam informasi yang ada. Dalam penelitian ini menggunakan teknik sampling total atau sensus dimana seluruh populasi yang ada penulis gunakan sebagai sampel. Sumber data yang digunakan yaitu data sekunder yang diperoleh dari website resmi.

\section{Hasil dan Pembahasan}

Dalam penelitian ini data penelitian diperoleh dari website resmi Bursa efek indonesia www.idx.co.id.

Data tersebut merupakan laporan keuangan PT. Indosat Tbk. periode 2015-2018, beberapa data yang digunakan dalam penelitian ini diantaranya Laporan Keuangan (Neraca), Laporan Laba Rugi, Laporan Arus Kas. Penelitian ini menggunakan dua laporan keuangan berupa Neraca dan Laporan Laba Rugi karena dalam kedua laporan tersebut terdapat komponen pembentuk Laporan Arus Kas. Berikut ini hasil analisis Arus Kas yang diperoleh.

Tabel 3. Analisis Perbandingan Laporan Arus Kas PT. Indosat Tbk. Periode 2016-2018

\begin{tabular}{|c|c|c|c|c|c|c|c|c|}
\hline Tahun & & $\begin{array}{l}\text { Total anus kas } \\
\text { dari aktivitas } \\
\text { operasional }\end{array}$ & $\begin{array}{c}\text { Total anus las } \\
\text { dari aktivitas } \\
\text { investasi }\end{array}$ & $\begin{array}{l}\text { Total anus kas } \\
\text { daria akivitas } \\
\text { pendanaan }\end{array}$ & $\begin{array}{l}\text { Jumlah kenaikan } \\
\text { (peruunuman) bersih } \\
\text { kas dan setara kas }\end{array}$ & $\begin{array}{l}\text { Kas dan statara } \\
\text { kas anus kas, } \\
\text { awal periode }\end{array}$ & $\begin{array}{c}\text { Efele } \\
\text { perubahan } \\
\text { nilai kurs pada } \\
\text { kas dan setrata } \\
\text { kas }\end{array}$ & $\begin{array}{l}\text { Kas dan setara } \\
\text { kas anus kas, } \\
\text { athiip periode }\end{array}$ \\
\hline \multirow{2}{*}{2015} & $\mathrm{Rp}$ & - & - & - & . & - & - & - \\
\hline & $\%$ & . & . & . & . & . & - &.- \\
\hline \multirow{2}{*}{2016} & Rp & 1.044 .844 & $(146.022)$ & $(2.724 .271)$ & $(1.825 .499)$ & 143.335 & $(90.807)$ & (1.772.921) \\
\hline & $\%$ & $12 \%$ & $2.04 \%$ & $178.40 \%$ & $(5332.74 \%)$ & $4.12 \%$ & $(83.23 \%)$ & $(48.93 \%)$ \\
\hline \multirow{2}{*}{2017} & $\mathrm{Rp}$ & $(790.579)$ & 518.744 & 2.135 .941 & 1.864 .106 & $(1.772 .921)$ & (15.294) & 75.891 \\
\hline & $\%$ & (8.11\%) & $(7.11 \%)$ & $(50.24 \%)$ & $(104.07 \%)$ & $(48.93 \%)$ & (83.59\%) & $4.10 \%$ \\
\hline \multirow{2}{*}{2018} & Rp & $(4798.993)$ & 1.320 .727 & 2.740 .216 & 5922.274 & $(175.680)$ & 32.455 & (881.275) \\
\hline & $\%$ & $(53.55 \%)$ & $(19.50 \%)$ & $(129.54 \%)$ & $81258 \%$ & $(9.49 \%)$ & $1080.75 \%$ & $(45.75 \%)$ \\
\hline
\end{tabular}

(dinyatakan dalam jutaan rupiah)

sumber : data yang diolah penulis, 2020.

Keadaan arus kas PT. Indosat Tbk. pada tahun 2016 mengalami kenaikan sebesar $12 \%$ atau ${ }^{\mathrm{Rp}} 1.044 .844$ namun pada aktivitas investasi terjadi kenaikan $2 \%$ atau sebesar ${ }^{\mathrm{Rp}} 145.827$, dan pada aktivitas pendanaan terjadi kenaikan arus yang membuat arus kas keluar bertambah sebesar $\mathrm{Rp}_{2}$.725.528. Pada tahun 2017 persentase perbandingan laporan arus kas cenderung mengalmai penuruan pada aktivitas operasi sebesar $-8,11 \%$ atau sebesar ${ }^{\mathrm{Rp}} 790.848$, lalu pada aktivitas investasi dan aktivitas pendanaan terjadi penurunan arus kas keluar sebesar -7,11\% dan -50,24\% atau sebesar ${ }^{\mathrm{Rp}} 518.417$ dan ${ }^{\mathrm{Rp}}$ 2.135.876. Sedangkan pada tahun 2018 terjadi penurunan yang cukup signifikan yaitu sebesar $-53,55 \%$ atau sebesar ${ }^{\mathrm{Rp}}-4.798 .581$ pada aktivitas operasi, pada aktivitas investai terjadi penurunan arus kas keluar sebesar $-19,5 \%$ atau sebesar ${ }^{\mathrm{Rp}} 1.320 .665$, dan pada aktivitas pendanaan terjadi penurunan arus kas keluar sebesar $-129,5 \%$ yang berarti sebesar ${ }^{\mathrm{Rp}} 2.739 .450$. 
Hal tersebut terjadi karena adanya perubahan pada beberapa komponen pada neraca seperti menurunnya penjualan dan pendapatan usaha, bertambahnya piutang atau piutang yang tidak tertagih, serta bertambahnya utang pada perusahaan sehingga membuat arus kas terutama arus kas pada aktivitas operasi mengalami penurunan terutama pada tahun 2018 yang mengalami penurunan secara signifikan. Sedangkan komponen yang terdapat pada laporan laba rugi, laporan laba rugi kenaikan beban setiap tahunnya sangat mempengaruhi perubahan pada laporan arus kas.

Tabel 4. Analisis Trend Laporan arus kas PT. Indosat Tbk. periode 2016-2018

(dalam juataan rupiah)

\begin{tabular}{|c|c|c|c|c|}
\hline Keterangan & 2015 & 2016 & 2017 & 2018 \\
\hline $\begin{array}{l}\text { Total arus kas dari } \\
\text { aktivitas } \\
\text { operasional }\end{array}$ & - & $112,00 \%$ & $91,89 \%$ & $46,45 \%$ \\
\hline $\begin{array}{l}\text { Total arus kas dari } \\
\text { aktivitas investasi }\end{array}$ & - & $102,04 \%$ & $92,89 \%$ & $80,50 \%$ \\
\hline $\begin{array}{l}\text { Total arus kas dari } \\
\text { aktivitas } \\
\text { pendanaan }\end{array}$ & - & $278,40 \%$ & $49,76 \%$ & $(29,54 \%)$ \\
\hline $\begin{array}{l}\text { Jumlah kenaikan } \\
\text { (penurunan) } \\
\text { bersih kas dan } \\
\text { setara kas }\end{array}$ & - & $\begin{array}{c}(5232,74 \\
\%)\end{array}$ & $(4,07 \%)$ & $912,58 \%$ \\
\hline $\begin{array}{l}\text { Kas dan setara kas } \\
\text { arus kas, awal } \\
\text { periode }\end{array}$ & - & $104,12 \%$ & $51,07 \%$ & $90,51 \%$ \\
\hline $\begin{array}{l}\text { Efek perubahan } \\
\text { nilai kurs pada } \\
\text { kas dan setara kas }\end{array}$ & - & $16,77 \%$ & $16,41 \%$ & $1180,75 \%$ \\
\hline $\begin{array}{l}\text { Kenaikan } \\
\text { (penurunan) kas } \\
\text { dan setara kas } \\
\text { lainnya }\end{array}$ & - & - & - & - \\
\hline $\begin{array}{l}\text { Kas dan setara kas } \\
\text { arus kas, akhir } \\
\text { periode }\end{array}$ & - & $51,07 \%$ & $104,10 \%$ & $54,25 \%$ \\
\hline
\end{tabular}

Sumber : data yang diolah penulis, 2020.

Berdasrkan data sebelumnya Trend yang terjadi pada pada arus kas pada PT. Indosat Tbk. periode 2016-2018 cenderung menurun. Pada hasil olah data pada tahun 2016 analisis tren pada aktivitas operasi menunjukan angka persentase sebesar $112 \%$ yang berarti meningkat sebesar $12 \%$ dari tahun sebelumnya, sedangkan pada tahun 2017 analisis Trend menunjukan angka persentase sebesar 91,89\% hal ini berarti pada tahun 2017 terjadi kecenderungan penurunan sebesar $(-8.17 \%)$, hal ini pun terjadi pada tahun 2018 dengan kecenderungan penurunan sebesar $(-53,55 \%)$ dengan angka yang dihasilkan pada tahun 2018 pada aktivitas operasi hanya sebesar $46,45 \%$. Begitupun pada aktivitas investasi yang mengalami kecenderungan penurunan dimana dari tahun 2016 hingga 2018 berturut-turut hanya menghasilkan angka persentasi sebesar $102,04 \%$, 92,89\% dan
$80,50 \%$ yang berarti setiap tahun mengalami penurunan, di tahun 2017 sebesar 7,11\%, dan di tahun 2018 sebesar $19.50 \%$. Namun pada aktivitas investasi penurunan yang terjadi berarti terjadinya penurunan arus kas keluar, hal ini karena arus kas yang ada pada aktivitas investasi merupakan arus kas negatif. Lalu pada pada aktivitas pendanaan terjadi penurunan yang sangat signifikan dimana pada tahun 2016 angka persentase menunjukan angka $278,40 \%$ mengalami penurunan sebesar $50,24 \%$ menjadi $49,76 \%$, pada tahun 2017 dan pada tahun 2018 terjadi penurunan menjadi (-29.54\%). Seperti halnya pada aktvitas investasi penurunan pada aktivitas pendanaan merupakan penurunan pada arus kas keluar karna rus kas pendanaan merupakan arus kas negatif dan pada tahun 2018 pada aktivitas pendanaan terjadi arus kas positif karena pada aktivitas pendanaan menghasilkan kas positif. Sehingga pada total arus kas menghasilkan prersentase sebesar $51,07 \%$ pada tahun 2016, sebesar $104,10 \%$ pada tahun 2017, dan sebesar $54,25 \%$ pada tahun 2018 , dapat dilihat pada tahun 2017 menglami keniakan sebesar 4,10\% dari tahun sebelumnya hal ini dapat terjadi karena penurunan pada aktivitas investasi dan aktivitas pendanaan di tahun 2017 menghasilkan arus kas pada tahun 2017 menjadi meningkat.

Tabel 5. Analisis Persentase Perkomponen Arus Kas Masuk Laporan Arus Kas PT. Indosat Tbk. Periode 2016-2018

(dalam jutaan rupiah)

\begin{tabular}{cccccc}
\hline & $\begin{array}{c}\text { Total Arus } \\
\text { Kas Masuk }\end{array}$ & $\begin{array}{c}\text { Kas Masuk } \\
\text { Dari } \\
\text { Aktivitas } \\
\text { Operasi }\end{array}$ & $\begin{array}{c}\text { Total Arus Kas } \\
\text { Masuk Dari } \\
\text { Aktivitas } \\
\text { Investasi }\end{array}$ & $\begin{array}{c}\text { Total Anus Kas } \\
\text { Masuk Dari Aktivitas } \\
\text { Pendanaan }\end{array}$ & $\begin{array}{c}\text { Efek Perubahan Nilai } \\
\text { Kurs Pada Kas Dan } \\
\text { Setara Kas }\end{array}$ \\
\hline 2015 & $53,615,592$ & $37,611,449$ & 281,509 & $15,613,530$ & 109,104 \\
Persentase & & $70.15 \%$ & $0.53 \%$ & $29.12 \%$ & $0.20 \%$ \\
2016 & $50,671,554$ & $41,280,074$ & 93,183 & $9,280,000$ & 18,297 \\
Persentase & & $81.47 \%$ & $0.18 \%$ & $18.31 \%$ & $0.04 \%$ \\
2017 & $52,852,404$ & $40,552,934$ & 150,177 & $12,146,290$ & 3,003 \\
Persentase & & $76,73 \%$ & $0.28 \%$ & $22.98 \%$ & $0.01 \%$ \\
2018 & $42,154,160$ & $30,885,403$ & 144,299 & $11,089,000$ & 35,458 \\
Persentase & & $73.27 \%$ & $0.34 \%$ & $26,31 \%$ & $0.08 \%$ \\
\hline
\end{tabular}

Sumber: data yang diolah oleh penulis, 2020. 
Tabel 6. Analisis Persentase Perkomponen Arus Kas Keluar Laporan Arus Kas PT. Indosat Tbk. Periode 2016-2018

(dalam jutaan rupiah)

\begin{tabular}{ccccc}
\hline & $\begin{array}{c}\text { Total Arus Kas } \\
\text { Keuar }\end{array}$ & $\begin{array}{c}\text { Total Arus Kas } \\
\text { Keluar Dari } \\
\text { Aktivitas Operasi }\end{array}$ & $\begin{array}{c}\text { Total Arus Kas } \\
\text { Keluar Dari } \\
\text { Aktivitas Investasi }\end{array}$ & $\begin{array}{c}\text { Total Arus Kas } \\
\text { Keluar Dari } \\
\text { Aktivitas } \\
\text { Pendanaan }\end{array}$ \\
\hline 2015 & $(42.674 .435)$ & $(18.106 .956)$ & $(74.26 .873)$ & $(17.140 .606)$ \\
Persentase & & $42,43 \%$ & $17,40 \%$ & $40,17 \%$ \\
2016 & $(40.198 .178)$ & $(19.282 .262)$ & $(7.384 .569)$ & $(13.531 .347)$ \\
Persentase & & $47,97 \%$ & $18,37 \%$ & $33,66 \%$ \\
2017 & $(41.174 .544)$ & $(19.990 .029)$ & $(6.922 .819)$ & $(14.261 .696)$ \\
Persentase & & $48,55 \%$ & $16,81 \%$ & $34,64 \%$ \\
2018 & $(36.025 .190)$ & $(19.964 .786)$ & $(5.596 .214)$ & $(10.464 .190)$ \\
Persentase & & $55,42 \%$ & $15,53 \%$ & $29,05 \%$ \\
\hline
\end{tabular}

Sumber data yang diolah oleh penulis, 2020.

Berdasarkan data analisa perkomponen sebelumnya bahwa arus kas masuk pada PT. Indosat Tbk. sebagian besar dihasilkan dari aktivitas operasi dan aktivitas pendanaan hal ini karena kas operasi merupakan sumber kas internal utama yang digunakan untuk kegiatan perusahaan baik bagi kegiatan operasi kembali, aktivitas pengeluaran modal dan investasi, sedangkan pada aktivitas pendanaan merupakan kas masuk eksternal yang biasanya berupa pinjaman dari bank.

Namun kas masuk pada aktivitas operasi PT. Indosat Tbk. cenderung mengalami penurunan. Hal tersebut terjadi karena meskipun pada tahun 2017 kas masuk yang di terima cenderung meningkat, namun persentase yang di terima dari aktivitas investasi pada tahun 2017 ini cenderung menurun yaitu hanya sebesar $76,73 \%$, hal ini terbukti ketika pada tahun 2016 persentase pada aktivitas operasi yang di terima adalah sebesar $81,47 \%$ dan pada tahun 2018 sendiri kembali megalami penurunan sebesar $73,27 \%$.

Lalu pada aktivitas investasi mengalami kenaikan arus kas masuk setiap tahunnya masing masing sebesar $0,18 \%$ pada tahun 2016 , sebesar $0,28 \%$ pada tahun 2017 , dan sebesar $0,34 \%$ pada tahun 2018, dan pada tahun aktivitas pendanaan mengalami kenaikan pda setiap tahunnya masing masing sebesar $18,31 \%$ pda tahun $2016,22,98 \%$ pada tahun 2017, dan 26,31\% pada tahun 2018 . Sedangkan pada arus kas keluar pada aktivitas operasi PT. Indosat Tbk. cenderung mengalami kenaikan setiap tahunnya yaitu masing masing sebesar $47,97 \%$ pada tahun 2016 , sebesar $48,55 \%$ pada 2018 , dan $55,42 \%$ pada tahun 2018 . Lalu pada aktivitas investasi arus kas keluar mengalami penurunan setiap tahunnya meskipun penurunan yang terjadi cenderung sangat kecil yaitu sebesar $18,37 \%$ pada tahun 2016, sebesar $16,81 \%$ pada tahun 2018, sebesar $15,53 \%$ pada tahun 2018, begitu pun dengan aktvitas pendanaan yang mengalami penurunan sebesar $33,66 \%$ pada taun
2016, namun pada tahun 2017 kembali naik menjadi $34,64 \%$, dan kembali turun menjadi $29,05 \%$ pada tahun 2018. Pengeluaran yang terjadi sama halnya seperti arus kas masuk, arus kas keluar yang paling banyak merupakan kativitas operasi dan aktivitas pendanaan. Meskipun arus kas msauk masih tetap dapat menutupi kas keluar yang ada namun penurunan yang terjadi dapat mengakibat kan ketidak simbangan arus kas pada perusahaan.

Tabel 7. Total komponen pembentuk rasio kecukupan kas PT. Indosat Tbk periode 20162018

(dalam jutaan rupiah)

\begin{tabular}{lcccc}
\hline \multicolumn{1}{c}{ Keterangan/tahun } & 2016 & 2017 & 2018 & $\begin{array}{c}\text { Jumlah periode } \\
\text { 2016-2018 }\end{array}$ \\
\hline $\begin{array}{l}\text { Jumlah arus kas bersih yang } \\
\text { diperoleh dari (digunakan } \\
\text { untuk) aktivitas operasi }\end{array}$ & 9.751 .515 & 8.960 .936 & 4.161 .943 & 22.874 .394 \\
$\begin{array}{l}\text { Pembayaran untuk perolehan } \\
\text { aset tetap }\end{array}$ & $(7.207 .477)$ & $(209.240)$ & $(5.458 .311)$ & 12.875 .028 \\
$\begin{array}{l}\text { Pembayaran untuk perolehan } \\
\text { aset takberwujud }\end{array}$ & $(85.122)$ & 3.442 & $(54.324)$ & 142.888 \\
$\begin{array}{l}\text { Pembayaran untuk perolehan } \\
\text { kepemilikan pada entitas } \\
\text { asosiasi }\end{array}$ & $(91.970)$ & $(36.169)$ & $(83.579)$ & 211.718 \\
$\begin{array}{l}\text { penambahan persediaan } \\
\text { lainnya }\end{array}$ & 79.272 & 87.820 & 47.889 & 214.981 \\
$\begin{array}{l}\text { Pembayaran dividen dari } \\
\text { aktivitas pendanaan }\end{array}$ & $(125.432)$ & $(514.137)$ & $(476.296)$ & 1.115 .865 \\
\hline
\end{tabular}

Sumber : data yang diolah oleh penulis, 2020.

$$
\frac{22.874 .394}{13.229 .634+214.981+1.115 .865}=1.57 \rightarrow(6)
$$

Berdasarkan data yang telah disajikan sebeumnya, menunjukan bahwa perhitungan rasio kecukupan arus kas memperoleh nilai sebesar 1,57 yang artinya PT. Indosat Tbk. mampu memenuhi pertumbuhan operasi dan pertumbuhan deviden selama tiga periode yaitu 2016-2018 dengan menggunakan kas yang di hasilkan dari arus kas operasi. Hal ini dinilai baik, karena meskipun analisis perbandingan laporan keuangan dan analisis Trend pada arus kas operasi menunjukan penurunan namun PT. Indosat Tbk. tetap mampu memproyeksikan arus kas yang ada untuk memenuhi pertumbuhan investasi terutama pada investasi persediaannya dan pembayaran deviden selama periode 2016-2018 dengan hanya mengandalkan kas internal perusahaan. 
Tabel 8. Total komponen pembentuk rasio reinvestasi kas PT. Indosat Tbk. periode 20162018

(dalam jutaan rupiah)

\begin{tabular}{|c|c|c|c|c|}
\hline Keterangan/Tahun & 2016 & 2017 & 2018 & $\begin{array}{c}\text { Jumlah } \\
\text { Periode } \\
\text { 2016-2018 }\end{array}$ \\
\hline $\begin{array}{l}\text { Jumlah arus kas bersih yang } \\
\text { diperoleh dari (digunakan } \\
\text { untuk) aktivitas operasi }\end{array}$ & 9.751 .515 & 8.960 .936 & 4.161 .943 & 22.874 .394 \\
\hline $\begin{array}{l}\text { Pembayaran dividen dari } \\
\text { aktivitas pendanaan }\end{array}$ & $(125.432)$ & (514.137) & (476.296) & 1.115 .865 \\
\hline Aset tetap & 39.078 .409 & 35.891 .716 & 36.899 .330 & 111.869 .455 \\
\hline Good will & 1.324 .256 & 1.324 .383 & 1.324 .383 & 3.973 .022 \\
\hline $\begin{array}{l}\text { Aset takberwujud selain } \\
\text { goodwill }\end{array}$ & 115.955 & 272.459 & 246.627 & 635.041 \\
\hline $\begin{array}{l}\text { Aset keuangan tidak lancar } \\
\text { tersedia untuk dijual }\end{array}$ & 25.469 & 10.740 & 328.113 & 364.322 \\
\hline $\begin{array}{l}\text { Aset keuangan tidak lancar } \\
\text { lainnya }\end{array}$ & 68.342 & 85.406 & 231.293 & 385.041 \\
\hline $\begin{array}{l}\text { Biaya dibayar dimuka tidak } \\
\text { lancar }\end{array}$ & 1.190 .148 & 2.064 .338 & 1.980 .479 & 5.234 .965 \\
\hline Aset pajak tangguhan & 215.971 & 368.605 & 1.249 .018 & 1.833 .594 \\
\hline Aset imbalan pasca kerja & & 51.655 & & 51.655 \\
\hline $\begin{array}{l}\text { Aset tidak lancar non- } \\
\text { keuangan lainnya }\end{array}$ & 146.866 & 78.767 & & 225.633 \\
\hline Jumlah aset lancar & 8.073 .481 & 591.685 & 7.906 .525 & 16.571 .691 \\
\hline $\begin{array}{l}\text { Jumlah liabilitas jangka } \\
\text { pendek }\end{array}$ & $(19.086 .592)$ & $(16.200 .457)$ & (21.040.365) & $(56.327 .414)$ \\
\hline
\end{tabular}

Sumber : data yang dioleh oleh penulis, 2020

$\frac{22.874 .394-1.115 .865}{111.869 .455+4.608 .063+8.095 .210+-39.755 .723} \times 100 \%=25,65 \% \quad \rightarrow(7)$

Sedangkan pada rasio reinvestasi kas PT. Indosat Tbk. memperoleh nilai sebesar $25,65 \%$ persen, nilai rasio yang dihasilkan dari analisis reinvestasi dinilai sangat memuaskan. Dengan begitu selama periode 2016-2018 PT. Indosat Tbk. memproyeksikan sebesar $25,65 \%$ kas operasi yang ditahan dan digunakan untuk diinvestasikan kembali terhadap aset dan pertumbuhan operasi.

\section{SIMPULAN DAN SARAN}

\section{Simpulan}

Kondisi arus kas pada PT. Indosat Tbk. pada periode 2016-2018, tidak mencapai target yang telah di tentukan pada tahun 2016 dan 2018. Pada hasil analisis Trend yang di lakukan dapat disimpulkan Trend yang terjadi bahwa pada periode 2016-2018 cenderung menurun, meskipun pada tahun 2017 mengalami kenaikan namun relatif kecil. Sedangkan pada hasil analisis perkomponen dapat disimpulkan bahwa arus kas masuk cenderung mengalami penurunan dan arus kas keluar mengalami kenaikan, yang keduanya didominasi oleh aktivitas operasi. Pada analisis rasio khusus arus kas dan rasio reinvestasi dapat disimpulkan bahwa meskipun kondisi arus kas pada PT. Indosat Tbk. berfluktuasi namun proyeksi dalam memenuhi pertumbuhan operasi dan pertumbuhan deviden serta dalam melakukan kegiatan investasi kembali kas yang ada selama periode 2016-2018 dinilai memuaskan.

\section{Saran}

PT. Indosat Tbk. dapat mengurangi angka piutang tak tertagih yang ada, hal ini diharapkan mampu menaikan arus kas masuk yang ada pada PT. Indosat Tbk. dengan meningkatnya arus kas masuk di harapkan dapat berpengaruh pada kondisi arus yang di harapkan dapat terus meningkat dan diharapkan dapat mempertahankan kemampuannya dalam memenuhi kebutuhan dan kemampuannnya dalam reinvestasi yang sudah baik.

\section{DAFTAR PUSTAKA}

Fahmi, Irham. 2017. Pengantar pasar modal. Bandung : Alfabeta.

Hery. 2015. Pengantar akuntansi comperhensive edition. Jakarta : Grasindo.

Jusup, Al. Haryono. 2017. Dasar-dasar akutansi jilid II Edisi ke 7. Yogyakarta : Sekolah tinggi ilmu ekonomi YKPN.

Kasmir. 2018. Analisis laporan keuangan. Depok : Rajagrafindo persada.

Munawir. 2014. Analisis laporan keuangan. Yogyakarta. Liberty yogyakarta.

Subramanyam, K.R. 2017. analisis laporan keuangan (Financial statement analysis edisi) 11 buku 1\&2. Jakarta : Salemba empat.

Sugiyono. 2019. Metode penelitian kuantitatif kualitatif dan R\&D. Bandung. Alfabeta.

Sutrisno. 2017. Manajemen keuangan teori, konsep dan aplikasi. Yogyakarta. : Ekonisia.

Van Horne, Jams C., John M. Wachowicz Jr. 2016. Prinsip-prinsip manajemen keuangan (fundamental of financial management). Jakarta : Salemba empat.

Zulganef. 2018. Metode penelitian bisnis dan manajemen. Bandung : Refika aditama.

https://id.wikipedia.org/wiki/PenyediajasaInternet

https://pengantarakuntansi1.wordpress.com/

https://id.wikipedia.org/wiki/Indosat_Ooredoo

https://inet.detik.com/telecommunication/d3075982/filosofi-ooredoo-dan-tarik-ulurindosat

$\underline{\text { www.idx.co.id }}$

www.idnfinancials.com

www.indosatoredoo.com 